\title{
Evaluation of a nonlethal technique for hemolymph collection in Elliptio complanata, a freshwater bivalve (Mollusca: Unionidae)
}

\author{
Lori L. Gustafson ${ }^{1,2,3,8}$, Michael K. Stoskopf ${ }^{1,3,5}$, Arthur E. Bogan ${ }^{1,4}$, \\ William Showers ${ }^{1,6}$, Thomas J. Kwak ${ }^{1,7}$, Shane Hanlon ${ }^{2,9}$, Jay F. Levine ${ }^{1,2, *}$ \\ ${ }^{1}$ Environmental Medicine Consortium, ${ }^{2}$ Population Health and Pathobiology and ${ }^{3}$ Department of Clinical Sciences; \\ College of Veterinary Medicine, North Carolina State University, Box 8401, Raleigh, North Carolina 27606, USA \\ ${ }^{4}$ North Carolina State Museum of Natural Sciences, 11 West Jones St., Raleigh, North Carolina 27601-1029, USA \\ ${ }^{5}$ Department of Environmental and Molecular Toxicology, Box 7633, College of Agriculture and Life Sciences, \\ ${ }^{6}$ Department of Marine, Earth and Atmospheric Sciences, Box 8208, College of Physical and Mathematical Sciences, and \\ ${ }^{7}$ US Geological Survey, North Carolina Cooperative Fish and Wildlife Research Unit, Box 7617, Department of Zoology; \\ North Carolina State University, Raleigh, North Carolina 27695, USA \\ ${ }^{8}$ Present address: USDA Animal and Plant Health Inspection Service, 16 Deep Cove Rd, Eastport, Maine 04631, USA \\ ${ }^{9}$ Present address: US Fish and Wildlife Services, Southwestern Virginia Field Office, 330 Cummings St., Abingdon, \\ Virginia 24210, USA
}

\begin{abstract}
Hemolymph, the circulatory fluid of bivalves, transports nutrients, respiratory gases, enzymes, metabolic wastes, and toxicants throughout the body. Hemolymph can provide information pertinent to health assessment of animals or populations, but is not commonly used in freshwater bivalves partly because of the lack of tested, practical techniques for its nonlethal collection. The objective of this study was to evaluate the effect of hemolymph collection on the growth and survival of Elliptio complanata, a freshwater bivalve (Unionidae). We describe a simple technique for the collection of hemolymph from the anterior adductor muscle sinus of E. complanata. To evaluate the effect of hemolymph sampling on mussel survival and growth, 30 mussels sampled using the technique and 30 unsampled controls were followed for 3 mo post collection. Nine animals were sampled 3 times over 7 mo to monitor effects of repeated sampling. No negative impacts on survival or growth were observed in either the singly or repeatedly sampled animals. We also compared the composition of hemolymph collected from the adductor muscle sinus with that collected from the ventricle of the heart. Calcium levels and cell count of hemolymph obtained from the adductor sinus and ventricle were significantly different. There was no significant difference between collection sites for magnesium, phosphorus, ammonia, protein, sodium, potassium, or chloride. We conclude that collection of hemolymph from the adductor sinus is safe for sampled E. complanata and should be explored as a relatively non-invasive, and potentially useful, approach to the evaluation of freshwater mussel health.
\end{abstract}

KEY WORDS: Unionidae $\cdot$ Freshwater mussels $\cdot$ Hemolymph $\cdot$ Nonlethal sampling Resale or republication not permitted without written consent of the publisher

\section{INTRODUCTION}

North America is home to the richest diversity of freshwater bivalves in the world (Williams et al. 1993). These animals, however, are in a state of accelerated decline, with approximately $70 \%$ of North American freshwater mussel species classified as endangered, threatened or of special concern (Williams et al. 1993). Losses of these ecologically important animals have been attributed to habitat destruction caused by riparian land development and agricultural impacts on neighboring rivers and streams (Bogan 1993). Fresh- 
water mussels play roles in water filtration, bioturbation, and nutrient cycling and retention (Hauer \& Lamberti 1996). They are also food sources for many riparian and aquatic animals (McMahon \& Bogan 2001).

Health assessment of freshwater bivalves traditionally involves lethal tissue collection from animals for histology (Chittick et al. 2001), contaminant (Muncaster et al. 1990, Cope et al. 1999), enzymatic (Doran et al. 2001, McMahon \& Bogan 2001) or energy analysis (Baker \& Hornbach 2000, McMahon \& Bogan 2001). These techniques have successfully identified unionid populations suffering the impacts of dramatic localized habitat degradation (Foe \& Knight 1987) or major infestations of invasive species (Baker \& Hornbach 2000). In these situations, because a large proportion of a localized population is affected, only a relatively small number of animals need be sampled to identify the health effect.

However, many devastating environmental threats are more insidious, with diffuse impacts. Health effects may be subtle and initially present a picture of low prevalence. Sampling restrictions on endangered or threatened populations limit access to these animals for health assessment or any other purpose. In these situations, lethal sampling of a small number of animals is unlikely to reveal statistically convincing information (Wobeser 1994, Doran et al. 2001). Suitable nonlethal methods for detection of health problems increase the feasibility of safely processing sufficient numbers of animals to identify inconspicuous trends.

Some relatively noninvasive techniques, such as mantle (Berg et al. 1995) and foot (Naimo et al. 1998) biopsy for glycogen analysis (Naimo et al. 1998, Patterson et al. 1999), are described and tested. A reliable technique for sampling hemolymph from freshwater mussels would complement and expand this current base protocol for nonlethal assessment of unionid health. Blood analysis is a routine component of the evaluation of vertebrate organ health, hydration status, immunologic competence, and nutritional status (Willard et al. 1994). Techniques for harvesting hemolymph from marine bivalves are common practice (Fyhn \& Costlow 1975, Ford 1986, Fisher et al. 1996a,b, Yanick \& Heath 2000), and circulatory fluids have been used in physiologic studies of freshwater mussels (Dietz 1974, Pynnonen 1994, Pekkarinen 1997, McMahon \& Bogan 2001). Hematologic responses to season (Pekkarinen 1997), dehydration and anoxia (Dietz 1974, McMahon \& Bogan 2001), transportation (Pekkarinen \& Suoranta 1995), and acidity (Pynnonen 1994) have been described. However, the health impacts of hemolymph collection from freshwater mussels have not been sufficiently evaluated.

Freshwater mussels have an open circulatory system (McMahon \& Bogan 2001). Hemolymph flows through a series of tissue sinuses. The adductor muscles, visible through gaping valves, hold particularly large tissue sinuses. We modified hemolymph collection procedures targeting the adductor muscles in oysters (Fisher et al. 1996a,b) and brackish-water clams (Fyhn \& Costlow 1975) for use in freshwater bivalves, and provide a preliminary evaluation of the techniques' efficacy when used in freshwater mussels of the common Elliptio complanata (Lightfoot 1786) complex.

\section{MATERIALS AND METHODS}

Study animals and husbandry. Elliptio complanata, ranging from 40 to $74 \mathrm{~mm}$ in length (median $=54.7$, first quartile $[\mathrm{Q} 1]=53.5$, third quartile $[\mathrm{Q} 3]=59.7$ ), were collected over a $2 \mathrm{~d}$ period in July 2000 from 2 forested streams northwest of Raleigh, North Carolina. One valve of each mussel was marked with plastic numbered tags (Hallprint tags) using methacrylate adhesive. The mussels were then placed in a single large indoor recirculating water system for the duration of the study. Animals were randomly assigned to hemolymph-collection and control groups using a random-numbers generator. Additional mussels were collected for technique development and validation. The animals were given $1 \mathrm{wk}$ to acclimate prior to initiation of the study.

The recirculating water system held approximately $1100 \mathrm{l}$ of city water that was dechlorinated with sodium thiosulfate prior to use. Ambient laboratory temperatures were maintained at $21^{\circ} \mathrm{C}$ with central air and heating systems. Additional water temperature control was facilitated with titanium heat exchangers (Aqua Logic). Temperature modes of 19 (range 17 to $24^{\circ} \mathrm{C}$ ) and $21^{\circ} \mathrm{C}$ (range 20 to $21^{\circ} \mathrm{C}$ ) were maintained for the 1 st and 2nd experiments, respectively. Lighting conditions were regulated to $14: 10 \mathrm{~h}$ light:dark each day. Water quality variables were monitored every 1 to 2 wk. Dissolved oxygen ranged from 7.5 to 11.9 (mode 8.5) $\mathrm{mg} \mathrm{l}^{-1}, \mathrm{pH}$ ranged from 7.4 to 8.2 (mode 7.9 ), hardness ranged from 43 to 98 (mode 56) $\mathrm{mg} \mathrm{l}^{-1}$, alkalinity ranged from 24 to 54 (mode 35) $\mathrm{mg} \mathrm{l}^{-1}$, total ammonia nitrogen ranged from 0 to 0.23 (mode 0.02 ) $\mathrm{mg} \mathrm{l}^{-1}$ and nitrate ranged from 0 to 4.6 (mode 2.8 ) $\mathrm{mg} \mathrm{l}^{-1}$. Thirty percent water changes were conducted every 5 to $10 \mathrm{~d}$. The animals were fed cultured live algae, consisting primarily of Scenedesmus sp., 4 to 5 times $\mathrm{wk}^{-1}$. The density of algae was estimated by reading absorbance at $425 \mathrm{~nm}$ and converting that number to approximate the quantity of algae cells (cells ml ${ }^{-1}$ ) using a laboratory standard curve. The estimated weekly total of fed algal cells, standardized to volume of aquarium water, averaged $91000 \mathrm{ml}^{-1}$ of water in the animal holding tank.

Hemolymph sampling technique. Hemolymph was collected by gently prying the shell open approxi- 
mately 2 to $3 \mathrm{~mm}$ with a thin knife. The shell was held open with tissue forceps. Under full-spectrum lighting, the anterior adductor muscle was visible between slightly gaping valves as a highly reflective glistening white muscle surface. This muscle mass was gently penetrated with a 25 ga 5/8 inch needle (Fig. 1), directed along a line parallel to the anterior edge of the shell valves (Fig. 2). Hemolymph was most easily collected using gentle intermittent suction. A successful collection from a $50 \mathrm{~g}$ animal yielded approximately $0.5 \mathrm{ml}$ fluid over $30 \mathrm{~s}$. If air was drawn during collection, it was often difficult to extract any additional hemolymph from the animal. In the current study, a draw was considered complete when either the target volume of $0.5 \mathrm{ml}$ was achieved, or when air was aspirated. The smallest volume collected in this study was $0.3 \mathrm{ml}$.

Technique development. Six animals were used in a preliminary study to examine alternative sites for hemolymph collection. Circulatory fluids of different origins can vary in composition and ease of collection. Tissue sinus and ventricular fluids represent circulat-

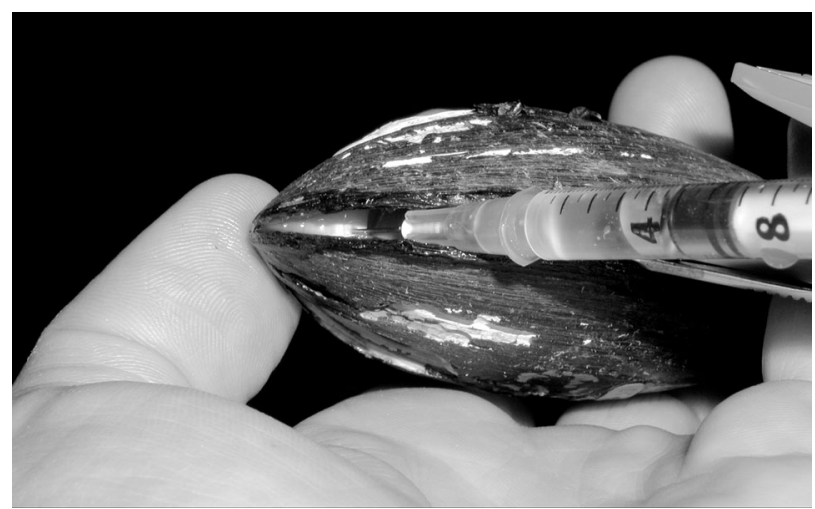

Fig. 1. Hemolymph collection from the anterior adductor muscle of Elliptio complanata

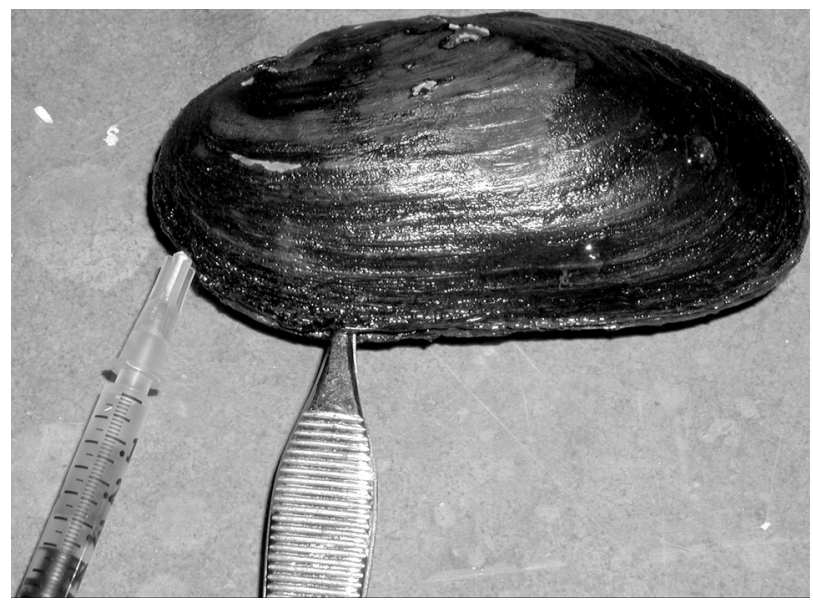

Fig. 2. Recommended needle alignment for hemolymph collection from Elliptio complanata ing hemolymph. Pericardial fluid has been routinely harvested from oysters (Friedl et al. 1988). Pericardial fluid, however, after passing through the cell junctions of the pericardial gland en route to the kidney, represents an ultrafiltrate of hemolymph (McMahon \& Bogan 2001). We initially attempted to collect fluid from the pericardial sinus or cardiac ventricles, via a hole drilled in the shell and through gaping valves in 3 mussels. These blind procedures lacked acuity: we found it difficult to ascertain whether our needle placement was cardiac or pericardial. These attempts also met with high mortality $(100 \%)$. Attempts to collect extrapallial fluid by needle insertion through mantle tissue were made in 3 additional animals. This approach did not produce adequate volumes (we achieved a maximum of $0.2 \mathrm{ml}$ per draw) of hemolymph. In contrast, the anterior adductor muscle sinus was readily accessed and visualized through gaping valves in the same animals and provided up to $1.5 \mathrm{ml}$ of fluid for analysis.

Four mussels were sacrificed to validate sample integrity. The collection location was confirmed by the needle track left on the cut surface of the adductor muscle of sacrificed mussels. This track appeared as a white line running to the center of the muscle mass (Fig. 3). We then compared the composition of fluids obtained from the adductor muscle and fluids obtained from direct (visually-aided, though lethal) sampling of the cardiac chamber. Ventricular hemolymph was accessed by gently prying (without transecting) the adductor muscles and mantle from their attachments to the shell, removing the upper valve, locating the beating ventricle, and sampling the ventricular fluid with a 25-gauge needle under a dissecting microscope. We ran cell counts on each sample by filling a Neubauer hemocytometer (Hausser Scientific) chamber with freshly drawn fluid and counting all cells in the corner

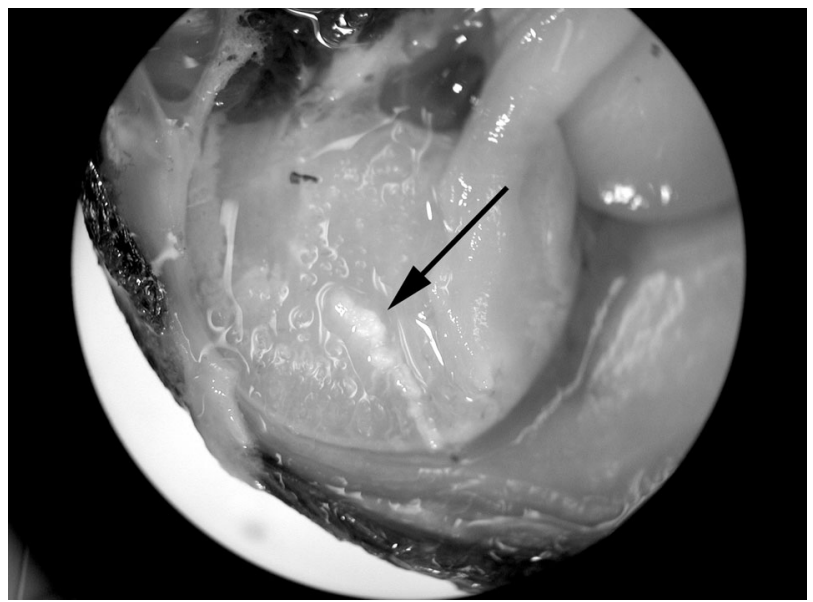

Fig. 3. Track left by a 25-gauge needle in the transected adductor muscle of Elliptio complanata 
squares. Fluid samples were analyzed within $24 \mathrm{~h}$ on an automated clinical chemistry analyzer (Hitachi 912, Roche Diagnostics) for colorimetric determination of total protein, ammonia, calcium, phosphorus and magnesium levels. Animals surviving these procedures were sacrificed by transecting the preserved adductor muscles. The goal of this analysis was assurance that the adductor muscle provides circulatory fluid comparable to that collected from the more traditionally sampled cardiac chamber. Parameters were chosen that could be expected to either vary substantially from water (e.g. cell count) or be somewhat identifiable to a particular individual (demonstrating greater variability between individuals than between fluid types). An extensive comparison of hemolymph compositions of 380 field-collected mussels for the purposes of establishing expected ranges for hemolymph parameters is presented as a separate study in a companion article (Gustafson et al. 2005, this issue).

Growth and survival studies. Our initial study compared survival and growth of a group of 30 mussels sampled for a single collection of hemolymph to that of 30 control animals maintained in identical conditions but not sampled for hemolymph over a 3 mo period (27 July to 31 October 2000$)$. Hemolymph $(0.5 \mathrm{ml})$ was collected from the anterior adductor muscle sinus of each treatment mussel once.

The 2nd study focused on the effect of repeated hemolymph sampling. Growth and survival were compared for 9 mussels sampled a total of 3 times (3 mo after initial sampling, and then again 2 mo later) and 9 control mussels similarly handled and measured but not hemolymph sampled. Mussels were monitored for a total of 7 mo ( 2 mo after the last sampling).

A full census was conducted once a month throughout the study, wherein all mussels were physically removed from the tank, counted, and weighed to the nearest $0.01 \mathrm{~g}$ in air (Mettler BB 240, Fisher Scientific). Shells were dried, but water was not forcibly removed from the mantle cavity prior to weighing. Mussels were also measured with Vernier calipers (Fisher Scientific) for shell length, width and height to the nearest $0.1 \mathrm{~mm}$. In addition, the holding tank was observed for mortalities during each feeding event in the first 2 mo and weekly thereafter.

Data analysis. Kruskal-Wallis analysis was used to identify growth differences between treatments (Hollander \& Wolfe 1999). Friedman tests (Hollander \& Wolfe 1999) identified possible relationships between the collection site, individual animals and the chosen hemolymph parameters. Nonparametric statistics were chosen to avoid misrepresentation of hemolymph values below instrument detection limits.

\section{RESULTS}

\section{Hemolymph composition and technique verification}

All fluid samples taken from the mussels were very different in composition from that of water (Table 1). Friedman tests, using individual as a blocking variable, established significant differences in calcium levels and cell counts obtained from the adductor sinus and ventricular chamber (Table 2). There was no significant difference $(H=3.08)$ between collection sites for magnesium, phosphorus, ammonia, protein, sodium, potassium, or chloride (Table 2).

\section{Growth and survival effects of one-time sampling}

There were no differences in survival rates between the control group and the hemolymph-sampled group. Both cohorts showed $97 \%$ survival at 1 mo and $90 \%$ survival at 3 mo.

We found no meaningful difference in 3 mo weight gain between the hemolymph-sampled and the control cohorts (Kruskal-Wallis, $\mathrm{p}=0.079, \mathrm{n}=27, H=3.08$, $\mathrm{df}=1$ ). Weight change for the control mussels ranged

Table 1. Elliptio complanata. Hemolymph parameters from the heart ventricle and adductor muscle sinus of 4 mussels. A water sample from a freshwater mussel holding tank is provided for comparison

\begin{tabular}{|c|c|c|c|c|c|c|c|c|c|c|}
\hline Individual & Source & Cells $\mu \mathrm{l}^{-1}$ & $\frac{\mathrm{Na}}{\left(\mathrm{mmol} \mathrm{l}^{-1}\right.}$ & $\begin{array}{c}\mathrm{K} \\
\left(\mathrm{mmol} \mathrm{l}^{-1}\right)\end{array}$ & $\begin{array}{c}\mathrm{Cl} \\
\left(\mathrm{mmol} \mathrm{l}^{-1}\right)\end{array}$ & $\begin{array}{l}\text { Phosphorous } \\
\left(\mathrm{mg} \mathrm{dl}^{-1}\right)\end{array}$ & $\begin{array}{c}\mathrm{Ca} \\
\left(\mathrm{mg} \mathrm{dl}^{-1}\right)\end{array}$ & $\begin{array}{c}\mathrm{Mg} \\
\left(\mathrm{mg} \mathrm{dl}^{-1}\right)\end{array}$ & $\begin{array}{c}\mathrm{NH}_{3} \\
\left(\mu \mathrm{mol} \mathrm{l}^{-1}\right)\end{array}$ & $\begin{array}{l}\text { Protein } \\
\left(\mathrm{mg} \mathrm{dl}^{-1}\right)\end{array}$ \\
\hline $\mathrm{A}$ & Adductor & 2640 & 16 & 0.5 & 18 & 0.9 & 19.3 & 2.7 & 44.1 & 73.3 \\
\hline $\mathrm{A}$ & Ventricle & 2020 & 17 & 0.6 & 18 & 0.8 & 21.7 & 2.9 & 37.7 & 73.5 \\
\hline B & Adductor & 960 & 15 & 0.5 & 18 & 0.8 & 17.9 & 2.7 & 26.4 & 41.9 \\
\hline B & Ventricle & 860 & 15 & 0.5 & 18 & 0.7 & 19.0 & 2.8 & 35.3 & 40.1 \\
\hline $\mathrm{C}$ & Adductor & 1490 & 18 & 0.6 & 18 & 0.9 & 17.0 & 2.8 & 26.8 & 72.6 \\
\hline $\mathrm{C}$ & Ventricle & 250 & 18 & 0.6 & 19 & 1.0 & 18.8 & 2.8 & 193.8 & 75.0 \\
\hline $\mathrm{D}$ & Adductor & 460 & 16 & 0.5 & 18 & 0.8 & 17.7 & 2.3 & 36.1 & 66.1 \\
\hline $\mathrm{D}$ & Ventricle & 420 & 15 & 0.5 & 17 & 0.8 & 18.3 & 2.3 & 46.9 & 60.4 \\
\hline Water & Tank & 0 & 5 & 0.4 & 4 & $<0.3$ & 1.0 & 0.3 & $<10$ & $<2$ \\
\hline
\end{tabular}


from -1.83 to $0.89 \mathrm{~g}$ (median $=-0.21 \mathrm{~g}, \mathrm{Q} 1=-0.98 \mathrm{~g}$, $\mathrm{Q} 3=0.35 \mathrm{~g})$. Weight change for the hemolymphsampled group ranged from -2.60 to $2.22 \mathrm{~g}$ (median $=$ $0.34 \mathrm{~g}, \mathrm{Q} 1=-0.45, \mathrm{Q} 3=0.71)$. Though not significant at an alpha level of 0.05 , the hemolymph-sampled group (rather than the control group) demonstrated greater weight gains. Shell growth over 3 mo was not significantly different between the hemolymph-sampled and the control cohorts (Kruskal-Wallis, $\mathrm{p}=0.789, \mathrm{n}=27$, $H=0.07, \mathrm{df}=1$ ). The change in shell size (estimated by the cubic root of shell length $\times$ width $\times$ height) for the control animals ranged from -1.15 to $1.05 \mathrm{~mm}$ (median $=0.19, \mathrm{Q} 1=-0.11, \mathrm{Q} 3=0.48$ ). The change in shell size for the hemolymph-sampled group ranged from -2.65 to $0.78 \mathrm{~mm}$ (median $=0.25, \mathrm{Q} 1=-0.16, \mathrm{Q} 3=0.52)$.

\section{Effects of repeated sampling}

There were no mortalities in either cohort. Furthermore, there were no significant differences in weight gain (Kruskal-Wallis, $\mathrm{p}=0.354, \mathrm{n}=9, H=0.86$, $\mathrm{df}=1$ ) or shell growth (Kruskal-Wallis, $\mathrm{p}=0.895, \mathrm{n}=9, H=0.02$, $\mathrm{df}=1$ ) between repeatedly sampled individuals and controls over the subsequent 7 mo (October 2000 to May 2001) study period. The change in animal weight ranged from -0.74 to $2.48 \mathrm{~g}$ for the treatment group (median $=-0.03, \mathrm{Q} 1=-0.31, \mathrm{Q} 3=0.72)$ and from -0.38 to $1.65 \mathrm{~g}$ for the controls (median $=0.34, \mathrm{Q} 1=0.13, \mathrm{Q} 3=$ 0.89 ). The change in shell size ranged from -0.49 to $3.25 \mathrm{~mm}$ for the treatment group (median $=0.00, \mathrm{Q} 1=$ $-0.22, \mathrm{Q} 3=0.34$ ) and from -1.07 to $0.32 \mathrm{~mm}$ for the controls (median $=0.00, \mathrm{Q} 1=-0.16, \mathrm{Q} 3=0.12$ ).

\section{DISCUSSION}

\section{Technique development and appraisal}

The chemical composition of hemolymph varied identifiably between individuals but only minimally by collection site. This provided assurance that the adductor muscle sinus is a suitable alternative to the more difficult cardiac chamber for hemolymph collection. Only calcium and cell count showed statistically significant differences between fluid types, with concentrations in the adductor muscle fluid generally higher than corresponding cardiac fluids. These differences in composition could have arisen due to sampling order. Adductor muscle fluids were, by necessity, always sampled and counted first, allowing a few minutes for potential margination of cells and/or dilution of circulatory fluids (Willard et al. 1994) with compensatory uptake of extravascular water. Differences in calcium were slight in magnitude.
Table 2. Elliptio complanata. Results from a Friedman test of difference between collection sites, using individual mussels as a blocking variable. Median values for the adductor muscle and ventricular fluids are presented, as well as the Friedman $S$-statistic and associated p-value

\begin{tabular}{|lcccc|}
\hline $\begin{array}{l}\text { Hemolymph } \\
\text { parameter }\end{array}$ & $\begin{array}{c}\text { Adductor } \\
\text { median }\end{array}$ & $\begin{array}{c}\text { Ventricle } \\
\text { median }\end{array}$ & $S$ & $\mathrm{p}$ \\
\hline Cell count $(\mu \mathrm{l})$ & 1070 & 710 & 4.0 & 0.046 \\
$\mathrm{Na}\left(\mathrm{mmol} \mathrm{l}^{-1}\right)$ & 16 & 16 & 0.0 & 1.0 \\
$\mathrm{~K}\left(\mathrm{mmol} \mathrm{l}^{-1}\right)$ & 0.53 & 0.53 & 1.0 & 0.317 \\
$\mathrm{Cl}\left(\mathrm{mmol} \mathrm{l}^{-1}\right)$ & 18 & 18 & 0.0 & 1.0 \\
$\mathrm{P}\left(\mathrm{mg} \mathrm{dl}^{-1}\right)$ & 0.85 & 0.80 & 0.33 & 0.564 \\
$\mathrm{Ca}\left(\mathrm{mg} \mathrm{dl}^{-1}\right)$ & 17.50 & 18.95 & 4.0 & 0.046 \\
${\mathrm{Mg}\left(\mathrm{mg} \mathrm{dl}^{-1}\right)}_{\mathrm{NH}\left(\mu \mathrm{mol} \mathrm{l}^{-1}\right)}^{2.75}$ & 2.80 & 2.0 & 0.157 \\
${\mathrm{Protein}\left(\mathrm{mg} \mathrm{dl}^{-1}\right)}^{36.3}$ & 68.2 & 67.1 & 1.0 & 0.317 \\
& & & 0.0 & 1.0 \\
\hline
\end{tabular}

Ventricular hemolymph was difficult to collect without injury to the organism. Furthermore, discerning whether the fluid was ventricular or pericardial in origin required the use of a dissecting microscope, and even then it was difficult. The anterior adductor muscle sinus, in contrast, was easy to access, produced a sizable quantity of fluid, and collection resulted in no obvious harm to the animal. Electrolyte values were comparable to those available from studies of related species (Dietz 1974, Pynnonen 1994). Consequently, we chose to focus on the anterior adductor muscle sinus for hemolymph collection efficacy studies.

\section{Efficacy analysis}

A limited number of studies have examined the impacts of hemolymph collection in marine (Ford 1986, Yanick \& Heath 2000) or brackish-water (Fyhn \& Costlow 1975) bivalve species, and have found no effects on survival. Our results on a freshwater species corroborate these earlier findings. We found that hemolymph sampling from the anterior adductor muscle sinus impacted neither survival nor growth in Elliptio complanata. Surprisingly, the singly sampled group displayed greater weight gain than the controls, though the difference was not statistically significant. Animals may hold variable amounts of water in their mantle cavity. Therefore, some precision was lost by our decision to minimize stress of handling and not forcibly remove mantle cavity water prior to weighing. All animals were handled and weighed in a consistent manner. Shell growth in this time frame and under our husbandry conditions was minor in both treatment groups.

Our findings of minimal growth over time, in both the treatment and control groups, are consistent with other studies of adult freshwater mussels in captivity. 
Attempts to house adult freshwater mussels in captivity for any length of time have met with limited success (Naimo et al. 2000). This is presumed to reflect inadequate diet. Survival rates were not affected by hemolymph sampling, even under the imperfect conditions of prolonged captivity. Consequently, unless there is increased vulnerability to predators following handling, it is likely that the procedure's safety will transfer to the context of the field environment.

\section{Utility of hemolymph analysis}

Freshwater bivalves inhabit a wide range of aquatic habitats, are sensitive to habitat disturbance and are fairly simple to collect (Hauer \& Lamberti 1996). Therefore, they are potentially important sentinel species for biomonitoring aquatic changes (McMahon \& Bogan 2001). They are also currently one of the most imperiled faunal groups in North America (Williams et al. 1993). The better their health and habitat requirements are understood, the more clearly we can target interventions to improve population and ecosystem recovery efforts. Our studies found that $0.5 \mathrm{ml}$ is a safe collection target volume for Elliptio complanata measuring 4 to $7 \mathrm{~cm}$ in shell length. With modification of target volumes and perhaps needle gauge, this technique is likely to be adaptable to different size classes and species of freshwater mussels. Circulatory fluid analysis may provide a non-lethal avenue for freshwater bivalve health assessment that is both simple to perform and minimally intrusive to populations under study.

Acknowledgements. We thank the College of Veterinary Medicine at North Carolina State University for providing funds and facilities necessary to conduct our study. Additional funds in support of these studies were provided by the North Carolina Department of Transportation. We also thank J. Johnson-Ratcliff and J. Alderman formerly with North Carolina's Wildlife Resources Commission, as well as T. Savidge formerly with North Carolina's Department of Transportation, for their continuing advice and support in the proper collection and handling of the animals used in this study. The North Carolina Cooperative Fish and Wildlife Research Unit is jointly supported by North Carolina State University, North Carolina Wildlife Resources Commission, US Geological Survey, and Wildlife Management Institute.

\section{LITERATURE CITED}

Baker SM, Hornbach DG (2000) Physiological status and biochemical composition of a natural population of unionid mussels (Amblema plicata) infested by zebra mussels. Am Midl Nat 143:443-452

Berg DJ, Haag WR, Guttman SI, Sickel JB (1995) Mantle biopsy: a technique for nondestructive tissue-sampling of freshwater mussels. J N Am Benthol Soc 14:577-581 Bogan AE (1993) Freshwater bivalve extinctions (Mollusca: Unionoidea): a search for causes. Am Zool 33:599-609

Chittick B, Stoskopf M, Law M, Overstreet R, Levine J (2001) Evaluation of potential health risks to Eastern Elliptio (Elliptio complanata) (Mollusca: Bivalvia: Unionidae) and implications for sympatric endangered freshwater mussel species. J Aquat Ecosyst Stress Recovery 9:35-42

Cope WG, Bartsch M, Rada RG, Balogh SJ, Rupprecht JE, Young RD, Johnson DK (1999) Bioassessment of mercury, cadmium, polychlorinated biphenyls, and pesticides in the upper Mississippi River with zebra mussels (Dreissena polymorpha). Environ Sci Technol 33:4385-4390

Dietz TH (1974) Body fluid composition and aerial oxygen consumption in the freshwater mussel, Ligumia subrostrata: effects of dehydration and anoxic stress. Biol Bull (Woods Hole) 147:560-572

Doran WJ, Cope WG, Rada RG, Sandheinrich MB (2001) Acetylcholinesterase inhibition in the threeridge mussel (Amblema plicata) by chlorpyrifos: implications for biomonitoring. Ecotoxicol Environ Saf 49:91-98

Fisher WS, Winstead JT, Oliver LM, Edmiston HL, Bailey GO (1996a) Physiologic variability of eastern oysters from Appalachicola Bay, Florida. J Shellfish Res 15:543-553

Fisher WS, Oliver LM, Edwards P (1996b) Hematologic and serologic variability of eastern oysters from Appalachicola Bay, Florida. J Shellfish Res 15:555-564

Foe C, Knight A (1987) Assessment of the biological impact of point source discharges employing asiatic clams. Arch Environ Contam Toxicol 16:39-51

Ford SE (1986) Effect of repeated hemolymph sampling on growth, mortality, hemolymph protein and parasitism of oysters, Crassostrea virginica. Comp Biochem Physiol 85A:465-470

Friedl FE, Alvarez MR, Johnson JS, Gratzner HG (1988) Cytometric investigations on hemocytes of the American oyster, Crassostrea virginica. Tissue Cell 20:933-939

Fyhn HJ, Costlow JD (1975) Anaerobic sampling of body fluids in bivalve molluscs. Comp Biochem Physiol 52A:265-268

Gustafson LL, Stoskopf MK, Showers W, Cope G and 5 others (2005) Reference ranges for hemolymph chemistries from Elliptio complanata of North Carolina. Dis Aquat Org 65:167-176

Hauer FR, Lamberti GA (1996) Methods in stream ecology. Academic Press, San Diego, CA

Hollander M, Wolfe DA (1999) Nonparametric statistical methods, 2nd edn. John Wiley \& Sons, New York

Lightfoot J (1786) A catalogue of the Portland Museum. Lately the property of the duchess Dowager of Portland, deceased, which will be sold at auction by Mr. Skinner and Co. London, vii + $194 \mathrm{pp}$

McMahon RF, Bogan AE (2001) Mollusca: Bivalvia. In: Thorp $\mathrm{JH}$, Covich AP (eds) Ecology and classification of North American freshwater invertebrates, 2nd edn. Academic Press, San Diego, CA, p 331-429

Muncaster BW, Hebert PDN, Lazar R (1990) Biological and physical factors affecting the body burden of organic contaminants in freshwater mussels. Arch Environ Contam Toxicol 19:25-34

Naimo TJ, Damschen ED, Rada RG, Monroe EM (1998) Nonlethal evaluation of the physiological health of unionid mussels: methods for biopsy and glycogen analysis. J N Am Benthol Soc 17:121-128

Naimo TJ, Cope WG, Monroe EM, Farris JL, Milam CD (2000) Influence of diet on survival, growth and physiological condition of fingernail clams Musculium transversum. J Shellfish Res 19:23-28 
Patterson MA, Parker BC, Neves RJ (1999) Glycogen concentration in the mantle tissue of freshwater mussels (Bivalvia: Unionidae) during starvation and controlled feeding. Am Malacol Bull 15:47-50

Pekkarinen M (1997) Seasonal changes in calcium and glucose concentrations in different body fluids of Anodonta anatina (L.) (Bivalvia: Unionidae). Neth J Zool 47:31-45

Pekkarinen M, Suoranta R (1995) Effects of transportation stress and recovery and sample treatment on calcium and glucose concentrations in body fluids of Anodonta anatina (L.). J Shellfish Res 14:425-433

Pynnonen K (1994) Hemolymph gases, acid-base status, and electrolyte concentration in the freshwater clams Anodonta

Editorial responsibility: Albert K. Sparks, Seattle, Washington, USA anatina and Unio tumidus during exposure to and recovery from acidic conditions. Physiol Zool 67:1544-1559

Willard MD, Tvedten H, Turnwald GH (1994) Small animal clinical diagnosis by laboratory methods, 2nd edn. WB Saunders, Philadelphia, PA

Williams JD, Warren ML Jr, Cummings KS, Harris JL, Neves RJ (1993) Conservation status of freshwater mussels of the United States and Canada. Fisheries 18:6-22

Wobeser GA (1994) Investigation and management of disease in wild animals. Plenum Press, New York

Yanick JF, Heath DD (2000) Survival and growth of mussels subsequent to haemolymph sampling for DNA. J Shellfish Res 19:991-993

Submitted: April 28, 2004; Accepted: January 4, 2005 Proofs received from author(s): June 28, 2005 